\title{
Biodiversity of Medicinal Plants in Homestead Garden of Bolpur- Sriniketan Block of West Bengal, India
}

\author{
Nisha Thakur ${ }^{1}$, Swagatika Das ${ }^{1}$, Raj Kumar Singh², Bholanath Mondal ${ }^{1 *}$
}

${ }^{1}$ Department of Plant Pathology, Palli-Siksha Bhavana (Institute of Agriculture), Visva-Bharati, Sriniketan, West Bengal, India

${ }^{2}$ Government General Degree College, Mangalkote, Panchanantala, Purba Burdwan, West Bengal, India

*Corresponding author: Bholanath Mondal

Abstract

Medicinal and Aromatic plants are economically important plants, rich in secondary metabolites and potential source of drugs, which provide basic raw materials for medicines, perfumes, flavours and cosmetics. The use of medicinal plants has attained an important role in health system all over the world. A comprehensive effort was made throughout Bolpur-Sriniketan block of West Bengal during 2018 -2019 to know the present status of medicinal plants in homestead garden. Among 80 households surveyed at 8 different villages in 4 Gram Panchayats of Bolpur-Sriniketan block, 36 households $(45 \%)$ have planted different types of medicinal plants in their Homestead garden. Nearly $77.78 \%$ marginalized tribal community started for nutritional gardening whereas $22.22 \%$ were from other communities. Different kinds of vegetables (20 numbers of 11 different families), fruits ( 7 numbers of 7 different families), flowers (3 numbers of 3 different families) and medicinal plants (15 numbers of 11 different families) were recorded in the homestead gardens. The most common medicinal plants recorded in the homestead garden are basak, Asiatic pennywort (thankuni), tulsi (holi basil), four leaf waterclover (sushni sag), turmeric (haldi), Indian aloe (ghritokumari), ginger (ada), thornapple (dhuntra), garlic (rasun), ashoka, golden apple (bael), belelvine (pan), waterhyssop (brahmi), swampweed (kulekhara), creat (kalmegh), stinkvine (gandal), air plant (patharkuchi) and neem. A parallel medical system has developed for curing common ailments. Though, it is an option for alternative livelihood but the local healers are unaware about the modern ayurveda system.

Keywords: Biodiversity, homestead garden, medicinal plant, traditional medicine.

Copyright @ 2020: This is an open-access article distributed under the terms of the Creative Commons Attribution license which permits unrestricted use, distribution, and reproduction in any medium for non-commercial use (NonCommercial, or CC-BY-NC) provided the original author and source are credited

\section{INTRODUCTION}

The World Health Organization (WHO) estimates that four billion people of the global population presently use flavouring medication for primary health care. Herbal medicine is a major element in people's traditional medicine and also a standard part in Homeopathic, ayurvedic, naturopathic, traditional oriental and Indian medicine. Herbal medicine refers to using a part of plants such as seeds, berries, roots, leaves, bark, or flowers for medicinal purposes. Herbal medicine broadly classified into various basic system: (i) Ayurvedic herbalism, which is derived from Ayurveda (ii) Traditional Chinese Herbalism, which is a part of Traditional Oriental Medicine and (iii) Western herbalism, originally came from Greece and Rome to Europe and then to North and South America.India is a land of biodiversity and rich source of Medicinal and Aromatic plants among them around $70 \%$ of the plants are spread across tropical forests of Western Ghats, Terai region, North East and Himalayas' regions. Among all the plants more than 20,000 plants are having therapeutic activity and they are now as modern medicinal crops from the wild plants by sustainable agricultural development in favourable climate and environmental conditions [1]. India has a very rich diversity of plant species in a wide range of ecosystems, about 17,000 species of higher plants, of which approximately 8,000 species are considered medicinal and utilized by village communities, particularly tribal communities, or in traditional medicinal systems, such as the Ayurveda [2]. The use of medicinal plants has attained an important role in health system all over the world. This involves the use of medicinal plants not only for the treatment of diseases but also as potential material for maintaining good health and conditions. Many countries in the world in that two-third of the population depend on herbal medicine for primary health care. The reason for this is because of their better cultural acceptability, better compatibility and adaptability with the human body and poses lesser side effects (https://www.tsijournals.com). Medicinal and Aromatic plants are economically important plants which provide basic raw materials for 
medicines, perfumes, flavours and cosmetics. These plants and their products help nation to earn valuable foreign exchange by way of export and also serve as valuable source of income for small holders and entrepreneurs. Medicinal plants such as aloevera, Tulsi, Neem, Turmeric, Ginger cure several common ailments. These are considered as home remedies in many parts of country. It is known that lot of peoples are using in their daily life for making medicine, black tea, in worship and other activities (https://agriinfo.in).

Red and Lateritic zone of West Bengal is one of the major sources of medicinal and aromatic plants. Some parts of the Birbhum district are tribal dominated. They used to cure their ailments mainly by collecting different types of herbs grown naturally in jungle, rode side or surrounding their home. Very little information has available about the cultivation of medicinal plants in homestead garden of the study area. Emphasis was given to record such information and their traditional uses in Birbhum district of West Bengal.

\section{MATERIALS AND METHODS}

A numbers of households were surveyed at 8 different villages in 4 Gram Panchayats (GP) of
Bolpur-Sriniketan block during February, 2018 to March, 2019 to record the presence of medicinal plants in homestead gardens. Stratified random sampling method was followed for the study. During survey some basic information viz. medicinal plants present in each homestead garden, plant parts used to cure ailments etc. were recorded. Besides, unstructured interviewing was made to some elderly local healers under tribal communities for collecting data regarding the use of such medicinal plants to cure common ailments.

\section{RESULTS AND DISCUSSION Status of Homestead Garden in Bolpur-Sriniketan Block}

The experiment revealed that among 80 households surveyed at 8 different villages (viz. Amdahara, Sahebdanga, Sukhbazar, Damdama, Keodaha, Kuchudanga, Barodanga and Sriniketan) in 4 Gram Panchayats (viz. Kankalitala, Sian Muluk, Albandha Sarpolehona and Ruppur) of Bolpur-Sriniketan block, 36 households $(45 \%)$ tried to cultivate different types of medicinal plants in their homestead garden for different purposes like curing ailments, for beautification or extra earnings (Table 1).

Table-1: Status of medicinal plants in homestead Garden in Bolpur-Sriniketan block

\begin{tabular}{|c|c|c|c|}
\hline Location & $\begin{array}{l}\text { Households } \\
\text { surveyed*(No.) }\end{array}$ & $\begin{array}{l}\text { Household having } \\
\text { medicinal plant (No.) }\end{array}$ & $\begin{array}{l}\text { Household having } \\
\text { medicinal plants }(\%)\end{array}$ \\
\hline \multicolumn{4}{|c|}{ GP - Kankalitala } \\
\hline Amdahara & 10 & 5 & 50 \\
\hline \multicolumn{4}{|c|}{ GP - Sian Muluk } \\
\hline Sahebdanga & 10 & 3 & 30 \\
\hline Sukhbazar & 10 & 6 & 60 \\
\hline \multicolumn{4}{|c|}{ GP - Albandha Sarpolehona } \\
\hline Damdama & 10 & 2 & 20 \\
\hline Keodaha & 10 & 4 & 40 \\
\hline Kuchudanga & 10 & 3 & 30 \\
\hline Barodanga & 10 & 5 & 50 \\
\hline \multicolumn{4}{|l|}{ GP - Ruppur } \\
\hline Sriniketan & 10 & 8 & 80 \\
\hline Total & 80 & 36 & - \\
\hline
\end{tabular}

Most of the villagers having medicinal plants in their homestead garden under the study area were from marginalized tribal community $(77.78 \%)$ except a few $(22.22 \%)$ (Table1). The area is drought prone, and monocropping with rice is their traditional practice. It was also recorded from unstructured interviewing of the tribal respondents that the average annual income of each household is nearly Rs. 25000.00 (rupees twenty-five thousand only). As their income from agriculture is very low they were forced to shift their way of earnings as labour of mason or to migrate other places. Some are well known as Janguru, Gunin, Ojha or
Baidya, they are actually local healers. They are practicing through generations to cure common ailments of local people using different herbs. Previously they were collected such medicinal plants from road side or forests, but presently the local healers have taken interest to grow common medicinal plants in their homestead garden as alternative livelihood. During survey, it was also found that the medicinal plants in homestead garden are suffering from different biotic and abiotic stresses that should be investigated to minimize the situation. 
Nisha Thakur et al., Sch Acad J Biosci, August, 2020; 8(8): 244-248

\section{Common vegetation in the homestead garden}

Different kinds of vegetables (20 numbers of 11 different families), fruits ( 7 numbers of 7 different families) and flowers (3 numbers of 3 different families) plants were recorded in the homestead garden. The most common plants recorded in the homestead garden are amaranthus, poi, chilli, brinjal, tomato, okra, elephant foot yam, kidney been, papaya, jack fruit, citrus, marigold and periwinkle (Table 2). Most of the homestead gardens of tribal families have more or less similar lay out and same type of cropping pattern but there was some choice based cropping pattern recorded in the homestead garden of other than tribal families. The garden is generally maintained by woman and child members of the family. The tribal farmers are not aware about the recent technologies for managing their garden. So, management of the garden is very poor and consequently they are receiving lower yield. It is an interesting and hopeful observation that the tribal farmers are unaware with the chemical pesticides. They try to manage their garden by traditional way. On the other hand, a few gardeners other than tribal families are using pesticides for mznaging their nutritional garden.

Table-2: Common crops recorded in homestead garden

\begin{tabular}{|c|c|c|}
\hline Common name & Botanical name & Family \\
\hline \multicolumn{3}{|l|}{ Vegetables } \\
\hline Amaranthus & Amaranthus spp. & Amaranthaceae \\
\hline Beet & Beta vulgaris L. & Amaranthaceae \\
\hline Onion & Allium cepa $\mathrm{L}$. & Amaryllidaceae \\
\hline Colocasia & Colocasia esculenta ( L.) Schott. & Araceae \\
\hline Elephant foot yam & Amorphophallus paeoniifolius (Dennst.) Nicolson & Araceae \\
\hline Basella (Poi) & Basella alba $\mathrm{L}$. & Basellaceae \\
\hline Cabbage & Brassica oleracea L.var. capitata L. & Brassicaceae \\
\hline Cauliflower & Brassica oleracea L.var. botrytis L. & Brassicaceae \\
\hline Knolkhol & Brassica oleracea L. var. gongylodes L. & Brassicaceae \\
\hline Radish & Raphanus sativus L. & Brassicaceae \\
\hline Bottle gourd & Lagenaria siceraria (Molina) Standl. & Cucurbitaceae \\
\hline Pumpkin & Cucurbita maxima Duchesne & Cucurbitaceae \\
\hline Ivy gourd & Coccinia grandis (L.) Voigt & Cucurbitaceae \\
\hline Kidney been & Phaseolus vulgaris L. & Fabaceae \\
\hline Okra & Abelmoschus esculentus (L.) Moench & Malvaceae \\
\hline Chilli & Capsicum annuum $L$. & Solanaceae \\
\hline Tomato & Solanum lycopersicum L. & Solanaceae \\
\hline Brinjal & Solanum melongena L. & Solanaceae \\
\hline Potato & Solanum tuberosum L. & Solanaceae \\
\hline Carrot & Daucus carota subsp. sativus (Hoffm.) Schübl. \& G. Martens & Umbelliferae \\
\hline \multicolumn{3}{|l|}{ Fruits } \\
\hline Mango & Mangifera indica L. & Anacardiaceae \\
\hline Papaya & Carica papaya $\mathrm{L}$. & Caricaceae \\
\hline Jackfruit & Artocarpus heterophyllus Lam. & Moraceae \\
\hline Drumstick & Moringa oleifera Lam. & Moringaceae \\
\hline Banana & Musa paradisiaca $\mathrm{L}$. & Musaceae \\
\hline Guava & Psidium guajava L. & Myrtaceae \\
\hline Citrus & Citrus aurantifolia (Christm.) Swingle & Rutaceae \\
\hline \multicolumn{3}{|l|}{ Flowers } \\
\hline Periwinkle & Catharanthus roseus (L.) G.Don & Apocynaceae \\
\hline Marigold & Tagetes erecta $\mathrm{L}$. & Asteraceae \\
\hline Chinese rose & Hibiscus rosa-sinensis L. & Malvaceae \\
\hline
\end{tabular}

\section{Medicinal plants in the homestead garden}

Different kinds of medicinal plants were recorded in the homestead garden. The most eleven common medicinal plants recorded in the homestead garden are basak, Asiatic pennywort (thankuni), tulsi (holi basil), four leaf waterclover (sushni sag), turmeric (haldi), Indian aloe (ghritokumari), ginger (ada), thornapple (dhuntra), garlic (rasun), ashoka, golden apple (bael), belelvine (pan), waterhyssop (brahmi), swampweed (kulekhara), creat (kalmegh), stinkvine (gandal), air plant (patharkuchi) and neem (Table 3). These plants were under 15 different botanical families. Besides, some vegetables and fruits (papaya is used against constipation and indigestion, latex of papaya is used to cure Jaundice; drumstick leaves against small pox infection, citrus is against indigestion and skin 
Nisha Thakur et al., Sch Acad J Biosci, August, 2020; 8(8): 244-248

diseases) and flower (marigold as antiseptic to heal wounds; periwinkle to cure leukemia, diabetes and malaria) are also using by them as medicinal plants. They used such plants in curing ailments of human and animals. In most cases, tribal are very much reluctant to go to the hospital. Generally, they do not like to disclose or share their problems to others. That's why, a parallel medical system has developed and the man/woman who has engaged to such system (local healer) is popularly known as Janguru, Gunin, Ojha or Baidya [3]. Basically, they collect different parts of plants having medicinal value from jungle, rode side or from surrounding their home, and prepare dose for specific diseases (Table 3). The local healers do not take honorarium for discussion regarding the ailments; they take price of medicine in terms of money. This system of treatment has developed by trial and error method since long, and has passing through generation to generation. This is an alternative way of earnings but the local healers should learn about the modern ayurveda system.

Table-3: Name and parts of plants used by the local healers as medicine

\begin{tabular}{|c|c|c|}
\hline Name of plant & Plant parts used & Used for curing \\
\hline Basak (Justicia adhatoda L., Family: Acanthaceae) & Leaves & Cough and Cold, Asthama, Bronchitis \\
\hline Thornapple (Datura metel L., Family: Solanaceae) & Leaves, Seeds & $\begin{array}{l}\text { Asthma, Whooping cough, Bronchitis, Skin } \\
\text { diseases, Pain }\end{array}$ \\
\hline Holy basil (Ocimum basilicum L., Family: Lamiaceae) & Leaves & Cough, Bronchitis, Skin diseases \\
\hline Betelvine (Piper betle L., Family: Piperaceae) & Leaves and vine & $\begin{array}{l}\text { Indigestion, Respiratory problems, Asthma, } \\
\text { Chest and Lung congestion }\end{array}$ \\
\hline $\begin{array}{l}\text { Air plant (Bryophyllum pinnatum (Lam.) Oken, Family: } \\
\text { Crassulaceae) }\end{array}$ & Leaves and shoots & Diarrhoea \\
\hline $\begin{array}{l}\text { Indian Aloe (Aloe vera (L.) Burm. f., } \\
\text { Family: Aloaceae) }\end{array}$ & Leaves & Skin diseases, Constipation, Piles \\
\hline $\begin{array}{l}\text { Creat (Andrographis paniculata (Burm.f.) Nees, } \\
\text { Family: Acanthaceae) }\end{array}$ & Leaves and roots & Jaundice, Intestinal worms, Dysentery \\
\hline $\begin{array}{l}\text { Asiatic Pennywort (Centella asiatica (L.) Urban, } \\
\text { Family: Apiaceae) }\end{array}$ & Leaves & Dysentery, Eczema, Indigestion \\
\hline $\begin{array}{l}\text { Four Leaf Waterclover (Marsilea quadrifolia L., } \\
\text { Family: Marsileaceae) }\end{array}$ & Whole plant & Insomnia, Cough, Bronchitis, Diabetes \\
\hline $\begin{array}{l}\text { Water hyssop (Bacopa monnieri (L.) Pennell, Family: } \\
\text { Plantaginaceae) }\end{array}$ & Whole plants & $\begin{array}{l}\text { Cancer, Cholesterol, Diabetes, Improve } \\
\text { memory and liver health }\end{array}$ \\
\hline $\begin{array}{l}\text { Swampweed (Hygrophila auriculata Schumach., } \\
\text { Family: Acanthaceae) }\end{array}$ & $\begin{array}{l}\text { Whole plant including } \\
\text { seeds and roots }\end{array}$ & Anaemia, Diarrhoea, Urinary problems \\
\hline Turmeric (Curcuma longa L., Family: Zingiberaceae) & Rhizome & $\begin{array}{l}\text { Skin diseases and Wounds, Septic, Blood } \\
\text { contamination }\end{array}$ \\
\hline $\begin{array}{l}\text { Ginger (Zingiber officinale Rosc., } \\
\text { Family: Zingiberaceae) }\end{array}$ & Rhizome & Breath problem, Indigestion \\
\hline Garlic (Allium sativum L., Family: Amaryllidaceae) & Bulb & $\begin{array}{l}\text { Pulmonary infection, Whooping cough, } \\
\text { Bronchitis, Hysteria }\end{array}$ \\
\hline $\begin{array}{l}\text { Ashoka (Saraca asoca (Roxb.) Willd., } \\
\text { Family: Fabaceae) }\end{array}$ & Flower, Bark & Astringent, Menstrual disorder, Diabetes \\
\hline $\begin{array}{l}\text { Golden apple (Aegle marmelos (L.) Correa, } \\
\text { Family:Rutaceae) }\end{array}$ & Fruit & Constipation, Bile problem \\
\hline Stinkvine (Paederia foetida L., Family: Rubiaceae) & Leaves & Dysentery, Diarrhoea \\
\hline Neem (Azadirechta indica A. Juss., Family: Meliaceae) & Leaves, Seeds & $\begin{array}{l}\text { Jaundice, Intestinal worms, Small pox, } \\
\text { Leprosy, Skin diseases }\end{array}$ \\
\hline
\end{tabular}

\section{CONCLUSION}

The local healers are the treasure of information. Need more intervention to record and conserve such useful information from local healers for future use. If more people express their interest in growing medicinal plants in homestead garden, proper marketing channel will be developed, which will open a new window for employment of the rural youth.

\section{CONFLICT OF INTEREST}

The authors declare that no conflict of interest exists in the course of conducting this research. All authors had final decision regarding the manuscript and the decision to submit the findings for publication. 
Nisha Thakur et al., Sch Acad J Biosci, August, 2020; 8(8): 244-248

\section{ACKNOWLEDGEMENT}

The authors are thankful to homestead gardeners for the field study. The study is a part of M. Sc. dissertation of the first author, Smt. Nisha Thakur under the guidance of the fourth author, Dr. Bholanath Mondal. Rest two authors (Smt. Swagatika Das and Dr. Raj Kumar Singh) were assisted in different ways during the study.

\section{REFERENCES}

1. Das K, Tiwari RKS, Shrivastava DK. Techniques for evaluation of medicinal plant products as antimicrobial agent: Current methods and future trends. Journal of Medicinal Plants Research. 2010; 4(2): 104-111.

2. Davidson-Hunt I. Ecological ethno botany: stumbling toward new practices and paradigms. MASA Journal. 2000; 16: 1-13.

3. Mondal B, Sarkar NC, Mondal CK, Maiti RK, Rodriguez HG. Mangrove plants and traditional ayurvedic practitioners in Sundarbans region of West Bengal, India. Research on Crops. 2012; 13(2): 669-674. 